\title{
Hematological and demographic profile of Pakistani children with isolated ventricular septal defects (VSDs)
}

Sumbal Sarwar', Shabana ${ }^{1 *}$ D, Farah Ehsan ${ }^{1}$, Amna Tahir ${ }^{1}$, Mahrukh Jamil', Saleem Ullah Shahid ${ }^{1}$, Shahida Hasnain ${ }^{1}$, Asim Khan ${ }^{2}$ and Syed Najam Hyder ${ }^{3}$

\begin{abstract}
Background: Cardiac morphogenesis is a dynamic and complex process that involves a complex interaction of many genetic and environmental factors. Ventricular septal defects (VSDs) are the commonest congenital heart defects (CHDs), accounting for $\sim 40 \%$ of all cardiac malformations. In Pakistan, the prevalence of VSD is increasing (4-6 in 1000 live births). In the current study, we aimed to determine the pattern of different hematological parameters and various risk factors in VSDs in local pediatric patients. We recruited the clinically diagnosed VSD children $(n=125)$ from various hospitals. The diagnosis was made based on echocardiography, size, number, and exact location of the defect. Hematological parameters, chemical pathological assays, and liver function analysis were performed. The blood group distribution and various risk factors were also assessed. The statistical analysis was done using the SPSS (IBM statistics version 22) software.
\end{abstract}

Results: The results showed that for RBCs, 20\% of patients in category of 0 to 3 months are above normal range; for WBCs, $33.3 \%$ of patients are above normal range in category of $4-5$ years and $12-14$ years. For hemoglobin, highest percentage of patients was observed below normal range; $30 \%$ of patients in category of 0 to 3 months, $40 \%$ of patients in category $4-9$ months, $35.2 \%$ of patients in category of 10 months -3 years, and $33.3 \%$ of patients in category of 12-14 years were below normal range. For platelet count, 5.66\% patients were below normal range and $16.9 \%$ were above normal range. For prothrombin time (PT) and activated partial thromboplastin time (APTT) more than 90\% patients were in normal range value. Elevated ALP level and significantly lower albumin levels were observed. In age range of 13-14 years, 50\% patients were below range for both calcium and serum creatinine. The prevalence of cousin marriages was $62.3 \%$, about $60 \%$ mothers used antibiotics during pregnancy, $\mathrm{B}+$ ve and $\mathrm{O}+$ ve had the highest frequencies, and most of the patients were seen in age group of 2-35 months.

Conclusion: All tested parameters show divergence from normal values their predictive capabilities of VSDs. To the best of our knowledge, the present study is the first to report data on hematological parameters and demographic risk factor associated with VSDs, in the Pakistani children. This data may have implication on the characterization and diagnosis of VSDs as well as on the assessment of related risk factors.

Keywords: Ventricular septal defects (VSDs), Blood group distribution, Red blood cell count, White blood cell count, Platelet count, Liver functions, Chemical pathological tests

\footnotetext{
* Correspondence: shabana.mmg@pu.edu.pk

${ }^{1}$ Department of Microbiology and Molecular Genetics, University of the

Punjab, Lahore 54590, Pakistan

Full list of author information is available at the end of the article
}

\section{Springer Open}

(c) The Author(s). 2020 Open Access This article is licensed under a Creative Commons Attribution 4.0 International License, which permits use, sharing, adaptation, distribution and reproduction in any medium or format, as long as you give appropriate credit to the original author(s) and the source, provide a link to the Creative Commons licence, and indicate if changes were made. The images or other third party material in this article are included in the article's Creative Commons licence, unless indicated otherwise in a credit line to the material. If material is not included in the article's Creative Commons licence and your intended use is not permitted by statutory regulation or exceeds the permitted use, you will need to obtain permission directly from the copyright holder. To view a copy of this licence, visit http://creativecommons.org/licenses/by/4.0/. 


\section{Background}

In vertebrates, heart develops during fetal life. Cardiac morphogenesis is a complex process that requires a complex interaction of different factors, including the differentiation, proliferation, migration, commitment to perform normal physiology, programmed cell death, and coordination of cardiac cells. Genetic risk factors and environment can disrupt the normal physiology of cardiogenesis that may lead to a broad spectrum of heart anomalies [1]. Contemporary classification of cardiovascular abnormalities varies based on clinically specified anatomic lesions. The most common type is ventricular septal defect (VSD), accounting for up to $40 \%$ of all cardiac malformations $[2,3]$. VSD is the defect in the septum of the heart which separates the right and left ventricles. A common word for septum is "aperture or hole" and septal malformations in ventricles are called "hole in the heart" [4]. VSDs often present as complex heart phonotypes including double outlet right ventricle, tetralogy of fallot, atrial septal defects, and patent ductus arteriosus (PDA) [5]. The complex genetic control of heart development is a major factor for heterogeneous VSDs. Numerous polymorphisms and mutations of many genes (encoding for transcriptional factors, signal transduction pathway components, and structural heart proteins) involved in cardiac development are known to increase the risk factor of VSDs [6].

Pakistan population constitutes a unique ethnic group due to its religious, social, and cultural practices [7]. This region has quite high prevalence of genetic diseases due to high proportion of consanguineous marriages. According to a survey, more than $80 \%$ of spouses in Pakistan are blood relatives $[8,9]$. VSD cases are increasing in frequency, accounting for 4-6 in 1000 live births [10-12]. One study by Hassan et al. gave a preliminary data on the risk factors in developmental heart defects [13]. After this, from 2001 to 2017, there have only been five reports which all were retrospective and collected data from tertiary care hospitals [14-18].

Some studies have reported the common forms of VSD, but there is no data on the hematological parameters, chemical pathological parameters, liver function, prenatal risk factors (mother's age, father's age, family history of VSDs), and blood group distribution analysis among VSDs in the Pakistani pediatric patients. In the current study, we aimed to determine the pattern of these parameters with VSD in patients in the local population. Hematological parameters included white blood cell count (WBCs), red blood cell count (RBCs), hemoglobin level $(\mathrm{Hb})$, platelet count, prothrombin time (PT), and activated partial thromboplastin time (APTT). Chemical pathological assays include blood urea nitrogen (BUN), serum creatinine, calcium, sodium, and potassium level. Liver function test (LFT) analysis include total bilirubin, serum glutamic pyruvic transaminase (SGPT), serum glutamic oxaloacetic transaminase (SGOT), alkaline phosphatase (ALP), serum total protein, serum albumin, and gamma GT. In addition to that, we have also compared the blood group distribution among VSDs patients. This study also examines the significance of various common risk factors in VSDs patients.

\section{Methods}

Participants, study protocols, and ethical requirements

For the current cross-sectional study, we recruited the participants $(n=125)$ from various hospitals. The study was done with partner collaborating hospitals. A written informed consent was obtained from the parents of the pediatric patient. The study protocol was approved by the local Ethical Committee (approval No. SBS/390/17). All participants less than 15 years of age with acyanotic congenital heart disease referred to a tertiary referral center were included in the study. The diagnosis was made based on echocardiography. Size, number, and exact location of the defect as well as the magnitude of the shunt were identified by using two-dimensional and Doppler echocardiography. Pulmonary artery pressure was also estimated by using modified Bernoulli equation. Aortic valve prolapse and aortic regurgitation were noted. Severity of aortic regurgitation was assessed by using parameters like left ventricular end diastolic and systolic dimensions, Doppler flow velocity measurement and assessment of length, width, and area of regurgitant jet. All echocardiograms were performed by trained pediatric cardiologists. Patients with syndromic and seropositive isolated VSDs were excluded from the study. Categorization of the study population into various subgroups on basis of patient's age was also done. The age of the subjects ranged from new born baby to 168 months (Fig. 2). The proportion of males was $61.5 \%$ while of females was $38.5 \%$.

\section{Determination of hematological parameters}

Hematological parameters were measured in standard units, white blood cell count (WBC, ${ }^{*} 10^{3} / \mu \mathrm{l}$ ), red blood cell count $\left(\mathrm{RBC},{ }^{*} 10^{6} / \mu \mathrm{l}\right)$, hemoglobin level $(\mathrm{Hb})$ in $(\mathrm{g} /$ $\mathrm{dl})$, platelet count $\left(* 10^{3} / \mu \mathrm{l}\right)$, PT, and APTT (Sec) by using automated analyzer. For certain parameters, patient's normal ranges are different according to their age group and gender.

\section{Assessment of chemical pathological assays}

Similar to hematological parameters, chemical pathological assays were also measured in classified standard units, including blood urea nitrogen (BUN); serum creatinine; and calcium $(\mathrm{mg} / \mathrm{dL})$, sodium, and potassium levels $(\mathrm{mmol} / \mathrm{L})$. Chemical pathological assays have 
different normal range values in different age groups of children; therefore, study population was categorized into different categories.

\section{Liver function tests (LFTs) analysis}

Liver function analyses were done for all the children including, total bilirubin (mg/dL), SGPT (U/L), SGOT (U/L), alkaline phosphatase (AP) and gamma GT, serum total protein $(\mathrm{g} / \mathrm{dL})$, and serum albumin $(\mathrm{g} / \mathrm{dL})$. For all liver function assays, different groups were made on the basis of their normal value ranges.

Blood group determination and distribution among VSDs Blood group of patients was determined using standard $\mathrm{ABO}$ blood group typing procedure. We also figured out the distribution of various blood groups among VSDs patients.

\section{Conventional risk factors}

Various risk factors were determined in the current study including mother's age, father's age, socioeconomic status, patient's age, and SES. The data was collected on the family history of VSDs in first degree relative and in sibling and cousin marriage of parents. In addition to that, we also investigated about the parent's cousin marriage. Maternal health factors, e.g., use of antibiotics during pregnancy period was also investigated.

\section{Statistical analysis}

The results were analyzed using the Statistical Package for Social Sciences (SPSS, IBM statistics version 22) software. All assay value scale down in different groups according to respective normal range, and their percentages were measured. The descriptive data of quantitative variables, including mean, SD, and range, was determined. The subjects were grouped based on age, and appropriate analyses were then executed among these group.

\section{Results}

We compared hematological parameters in different subgroups of study population classified according to the range of hematological parameters (For the comparison of results with normal range, we first collected data from various hospitals then categorized the data according to age group of patients, shown in tables. Every category of age group has its own normal range, which we used for the comparison. Normal ranges for the all parameters vary among different population, ethnic groups, and geographic regions, so reference values of our local population were used).

It was observed that the values of white blood cell count (WBCs), red blood cell count (RBCs), hemoglobin level $(\mathrm{Hb})$, platelets, $\mathrm{PT}$, and APTT vary among study subjects. For RBCs, $20 \%$ of patients in category 0 to 3 months and 4-12 months are above normal range. While for WBCs, $33.3 \%$ of patients in category of $4-5$ years and 12-14years are above normal range. For hemoglobin, maximum patients had $\mathrm{Hb}$ below normal range, $30 \%$ of patients in category of 0 to 3 months, $40 \%$ of patients in category $4-9$ months, $35.2 \%$ of patients in category of 10 months -3 years, and $33.3 \%$ of patients in category of $12-14$ years were below normal range. For platelet count, $77.3 \%$ patients were in normal range, $5.66 \%$ were below normal range, and $16.9 \%$ were above normal range. For PT and APTT, more than $90 \%$ patients were in normal range value (All normal ranges are mentioned in Table 1).

Variations in blood urea nitrogen (BUN), serum creatinine, calcium, sodium, and potassium were analyzed in subgroups of VSDs. For calcium, in category 0 to 12 months, $5.55 \%$ patients were below normal range; in category of 1-12 years for both calcium and serum creatinine, 16.6\% patients were below normal range. In the same category for sodium, $16.6 \%$ patients were above normal range. While in category of 13-14 years for both calcium and serum creatinine, $50 \%$ patients were below normal range. For BUN $(\mathrm{mg} / \mathrm{dL})$, more than $14 \%$ patients were above normal range in study population (Table 2 ).

LFTs analyses revealed that for SGOT more than 50\% of patients were above normal range in category 0 to 12 months. For SGOT, $40 \%$ of patients were above normal range in category of females 1-14 years. For alkaline phosphatase, $40 \%$ of patients were above normal range in category of 1-14 years. For serum total protein, $13.33 \%$ patients were below normal range. While for gamma GT, most patients were in normal range value (Table 3). It was observed that the $\mathrm{B}+\mathrm{ve}$ and $\mathrm{O}+\mathrm{ve}$ had the equal highest frequencies among the study population of VSD patients. Blood group A + ve also had comparable higher frequency than other blood groups. Lowest frequency that was seen in our study population was O-ve (Fig. 1).

Various reported risk factors of VSD were analyzed. For the study population of current study, the minimum age of mother that was observed was 18 years old and for father it was 25 years. Maximum age observed in our population for mother was 36 years and for father 45 years (Table 4). Categorization of the study population into various subgroups on basis of patient's age was also done. We had range of age from new born baby to 168 months (Fig. 2). The highest frequency of patients was seen in age group of 2-35 months. Other risk factors were also assessed in the study group including use of antibiotics during pregnancy period, parent's cousin marriage, and disease among first degree relative and siblings. The results of these analyses are shown in Fig. 3. 
Table 1 Hematological parameters in study population

\begin{tabular}{|c|c|c|c|c|}
\hline Age & Parameters normal range & $\%$ below range & $\%$ within range & $\%$ above range \\
\hline \multicolumn{5}{|l|}{$\operatorname{RBCs}^{*}(10 \wedge 6 / \mu \mathrm{l})$} \\
\hline 0 to 3 months & $2.8-4.8$ & 0 & 80 & 20 \\
\hline 4-12 months & $3.2-5.2$ & 0 & 80 & 20 \\
\hline $1-3$ years & $3.6-5.2$ & 0 & 100 & 0 \\
\hline $4-11$ years & $3.7-5.8$ & 0 & 88 & 12 \\
\hline $12-14$ years & $4.0-5.8$ & 0 & 100 & 0 \\
\hline \multicolumn{5}{|l|}{ 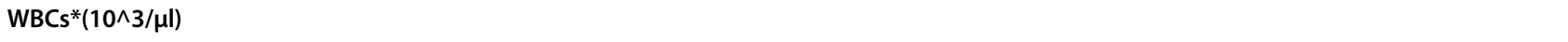 } \\
\hline 0 to 2 months & $5.5-18$ & 0 & 80 & 20 \\
\hline 3-12 months & $6-17.5$ & 0 & 91 & 9 \\
\hline $1-3$ years & $6-17$ & 0 & 75 & 25 \\
\hline $4-5$ years & $5-15.5$ & 33.3 & 33.3 & 33.3 \\
\hline $6-11$ years & $4.5-13.5$ & 0 & 100 & 0 \\
\hline $12-14$ years & $4-11$ & 0 & 66.6 & 33.3 \\
\hline \multicolumn{5}{|l|}{ Hemoglobin $(g / d l)$} \\
\hline 0 to 3 months & $9.6-13.6$ & 30 & 60 & 10 \\
\hline 4-9 months & $10.1-12.9$ & 40 & 53.3 & 6.6 \\
\hline 10 months-3 years & $10.7-13.1$ & 35.2 & 64.7 & 0 \\
\hline $4-7$ years & $10.7-14.7$ & 0 & 83.3 & 16.6 \\
\hline $8-11$ years & $10.8-15.6$ & 0 & 100 & 0 \\
\hline $12-14$ years & $11.5-16$ & 33.3 & 66.6 & 0 \\
\hline \multicolumn{5}{|l|}{ Others } \\
\hline Platelets* $(10 \wedge 3 / \mu \mathrm{l})$ & $200-550$ & 5.66 & 77.3 & 16.9 \\
\hline Prothrombin time PT (SEC) & $9-14$ & 5.66 & 92.4 & 1.88 \\
\hline Activated partial thromboplastin time APTT (SEC) & $22-31$ & 1.88 & 90.5 & 7.54 \\
\hline
\end{tabular}

Table 2 Chemical pathological assays in study population

\begin{tabular}{|c|c|c|c|c|c|}
\hline$\overline{\text { Age }}$ & Parameters & Normal range & $\%$ below range & $\%$ within range & $\%$ above range \\
\hline \multirow[t]{4}{*}{0 to 12 months } & Serum creatinine & $0.2-0.9$ & 0 & 100 & 0 \\
\hline & Calcium & $9-11$ & 5.55 & 91.6 & 2.77 \\
\hline & Sodium & 129-143 & 2.63 & 97.3 & 0 \\
\hline & Potassium & $3.6-5.8$ & 2.63 & 92.1 & 5.26 \\
\hline \multirow[t]{4}{*}{$1-12$ years } & Serum creatinine & $0.3-0.9$ & 16.6 & 83.3 & 0 \\
\hline & Calcium & $8.8-10.8$ & 16.6 & 83.3 & 0 \\
\hline & Sodium & $132-145$ & 0 & 83.3 & 16.6 \\
\hline & Potassium I & $3.1-5.1$ & 0 & 100 & 0 \\
\hline \multirow[t]{4}{*}{$13-14$ years } & Serum creatinine & $0.5-0.9$ & 50 & 50 & 0 \\
\hline & Calcium & $8.6-10.2$ & 50 & 50 & 0 \\
\hline & Sodium & $135-145$ & 0 & 100 & 0 \\
\hline & Potassium & $3.3-5.1$ & 0 & 100 & 0 \\
\hline 0 to 14 years & Blood urea nitrogen (BUN) (mg/dL) & $8-22$ & 25 & 60.41 & 14.58 \\
\hline
\end{tabular}


Table 3 Liver function analysis in study population

\begin{tabular}{|c|c|c|c|c|c|}
\hline Age & Parameters & Normal range & $\%$ below range & $\%$ within range & $\%$ above range \\
\hline \multirow[t]{2}{*}{0 to 12 months (both gender) } & (SGPT) U/L & $5-54$ & 0 & 89.47 & 10.52 \\
\hline & $(\mathrm{SGOT}) \mathrm{U} / \mathrm{L}$ & $5-82$ & 0 & 47.22 & 52.77 \\
\hline \multirow[t]{2}{*}{ Female } & (SGPT) U/L & $5-31$ & 0 & 100 & 0 \\
\hline & $(\mathrm{SGOT}) \mathrm{U} / \mathrm{L}$ & $5-32$ & 0 & 60 & 40 \\
\hline \multirow[t]{2}{*}{ Male } & (SGPT) U/L & $5-41$ & 0 & 88.8 & 11.11 \\
\hline & $(\mathrm{SGOT}) \mathrm{U} / \mathrm{L}$ & $5-38$ & 0 & 77.77 & 22.22 \\
\hline \multirow[t]{2}{*}{0 to 12 months } & Alkaline phosphatase U/L & $35-449$ & 2.63 & 92.10 & 5.71 \\
\hline & Serum total protein $\mathrm{g} / \mathrm{dL}$ & $4.8-5.4$ & 0 & 94.72 & 5.26 \\
\hline \multirow[t]{2}{*}{$1-14$ years } & Alkaline phosphatase U/L & $35-290$ & 0 & 60 & 40 \\
\hline & Serum total protein $\mathrm{g} / \mathrm{dL}$ & $6-8$ & 13.33 & 86.66 & 0 \\
\hline Male & Gamma GT U/L & $10-50$ & 0 & 93.75 & 6.25 \\
\hline Female & Gamma GT U/L & $7-32$ & 0 & 100 & 0 \\
\hline
\end{tabular}

\section{Discussion}

The increasing prevalence of genetic diseases in the Pakistani population, including developmental heart defects, has become alarming and poses a great burden on healthcare. The bulk of population belongs to lower middle class socioeconomic status, and for the parents of a patient's child with a heart defect, the cost of expensive treatment is too high to bear. This situation, coupled with a lack of understanding of how these defects form during fetal heart development and the lack of knowledge regarding how the genetic makeup of parents can contribute to such an anomaly, makes the condition even worse. In Pakistani population, there have been few studies presenting the epidemiological data of the types of such heart defects; however, no reports are available on different parameters and various risk factors in patients with these defects. The goal of the present study was to analyze the distribution of various parameters and risk factors, in children with VSDs in our population.

Red blood cell count, white blood cell count, platelet volume, hemoglobin level, PT, and APTT all are clinical profile biomarkers (used for the initial screening) for the heart anomalies. Deviation from the normal range is evident in various disorders, including heart defects [19]. Anemia affects more than one billion people worldwide, with a considerably high prevalence in pregnant women and children. Decreased hemoglobin levels and red blood cell count are the hallmarks of anemic condition [20]. In our study population, it was observed that majority of patients had $\mathrm{Hb}$ below normal range. More than $30 \%$ population of all categories of different age group

\section{Blood Group Distribution among VSD Patients}

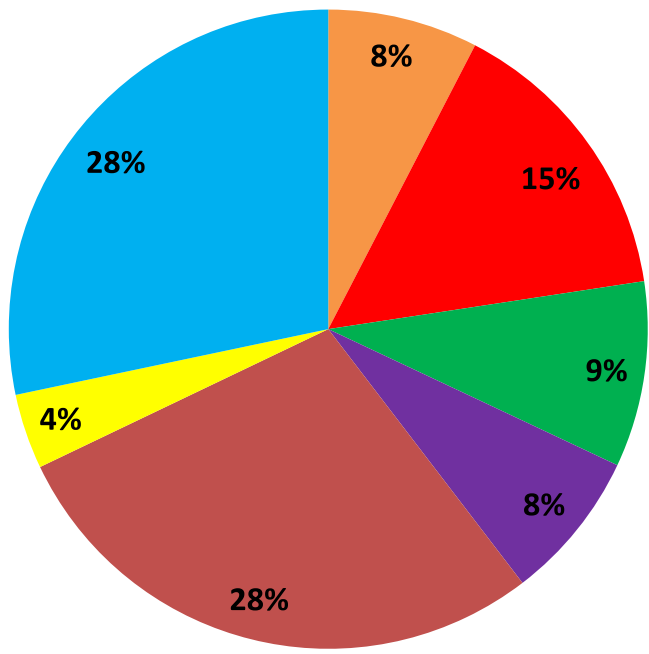

A-ve

A+ve

aB+ve

B-ve

B+ve

O-ve

O+ve

Fig. 1 Blood group distribution among VSD patients 
Table 4 Parents' age

\begin{tabular}{llllll}
\hline Parents' age & Minimum & Maximum & Mean & Std. error & Std. deviation \\
\hline Mothers' age & 18 & 36 & 28.67 & 1.222 & 4.731 \\
Fathers' age & 26 & 45 & 34.71 & 1.450 & 5.427 \\
\hline
\end{tabular}

had low Hb. White blood cell count above or below the normal range indicate altered immune function [21].

In pathological thrombosis, platelets are the active immune components and inflammation mediators. Platelets are the pivotal homeostatic elements at vascular injury site. Normal range of platelets is crucial for maintaining health and to avoid bleeding disorders [22]. Among our study population, variations could be seen for white blood cell count. More than $20 \%$ of study population was observed with low range of WBCs as compared to normal.

The serum anticoagulant activity can be measured by the standard plasma clotting time assays. The deviation from the normal ranges for APTT and PT suggest coagulation aberrations that may lead to bleeding disorders $[23$, 24]. The analyses of chemical pathological parameters turned out variations in these parameters as well. We also evaluated the elevated levels of potassium and sodium and decreased level of calcium. Our study population had high range of BUN in the blood. BUN is a strong risk factor for defective cardiovascular function. Constantly high level of urea, nitrogen, protein, and creatinine in the blood increases the risk of heart failure $[25,26]$. Elevated sodium level has been reported to be associated with the abnormal blood pressure [27]. A previous study reported that decreased calcium level is associated with the increased risk of sudden cardiac arrest [28].
Circulatory anomalies occur when more than one organ fail to perform normally. Normal liver function is crucial for the circulatory system. Liver failure and circulatory dysfunction are strongly related to one another $[29,30]$. Alkaline phosphatase (ALP) has been reported to be a biomarker for liver congestion in patients with heart failure [31]. The current cohort showed elevated ALP levels when compared to reference range. A previous study reported that elevated level for SGPT and SGOT and lower levels of albumin are associated with high mortality in the cardiovascular patients [32]. We also determined blood group distribution; it was observed that the blood group $\mathrm{B}+$ ve and $\mathrm{O}+$ ve had highest frequencies in the study population. Past several studies conducted in Pakistan showed that $\mathrm{B}+$ ve and $\mathrm{O}$ + ve blood group are the most frequent in this region [33-35]. Parameters including RBCs, WBCs, Platelets, $\mathrm{Hb}, \mathrm{ALP}, \mathrm{SGPT}, \mathrm{SGOT}$, and all others mentioned previously are not the risk factors for the congenital heart disease like VSDs, rather these parameters are deviated from normal range in individuals suffering from the developmental anomalies of the heart.

In Pakistan, consanguineous marriages are strong predisposing risk factor resulting in a high proportion of genetic diseases [9]. It is noteworthy that in current study the population of cousin marriages of parents was $62.3 \%$. Mother's age at pregnancy, educational background, bad obstetric history, intake of multivitamins containing folic acid during pregnancy, gestational diabetes, febrile illness during the first trimester, father's age, fetal birth weight, family history of VSD, cardiac anomalies in siblings, and socioeconomic status of the family have also been shown to be strong predictors of the risk of a neonate with a developmental heart defect $[36,37]$.

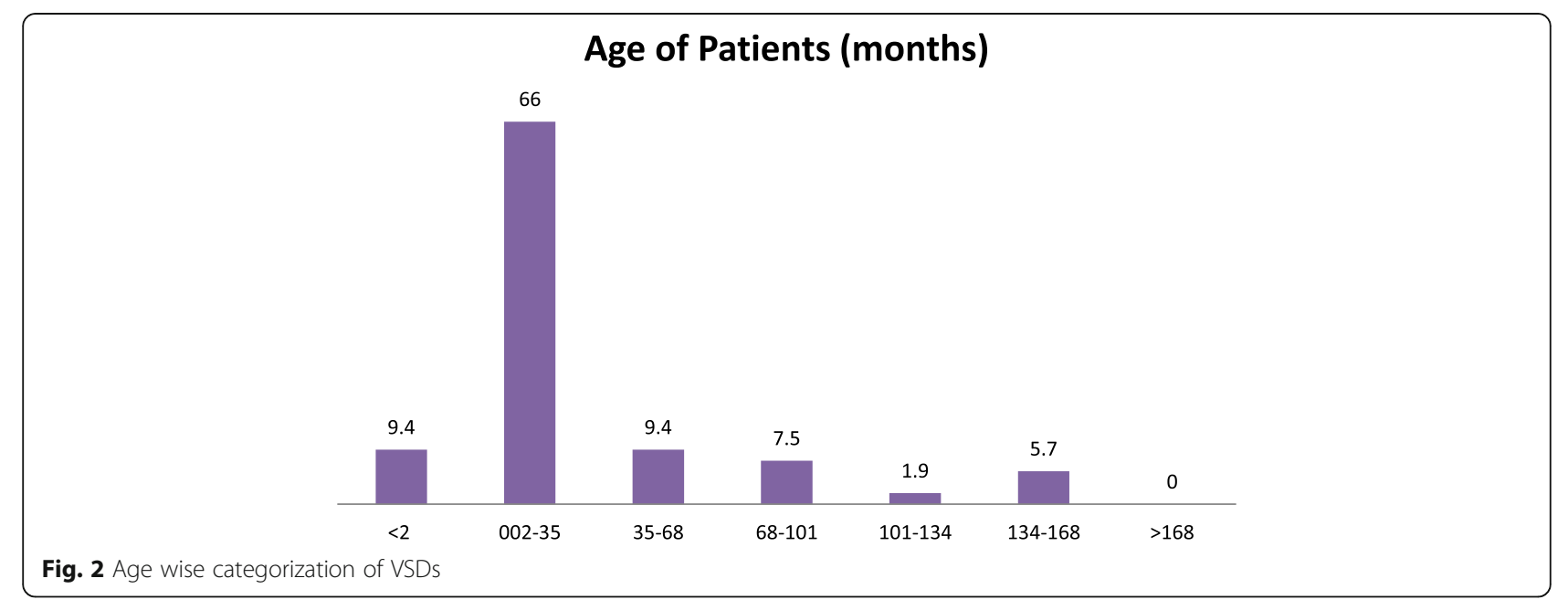




\section{Risk Factors of VSD}

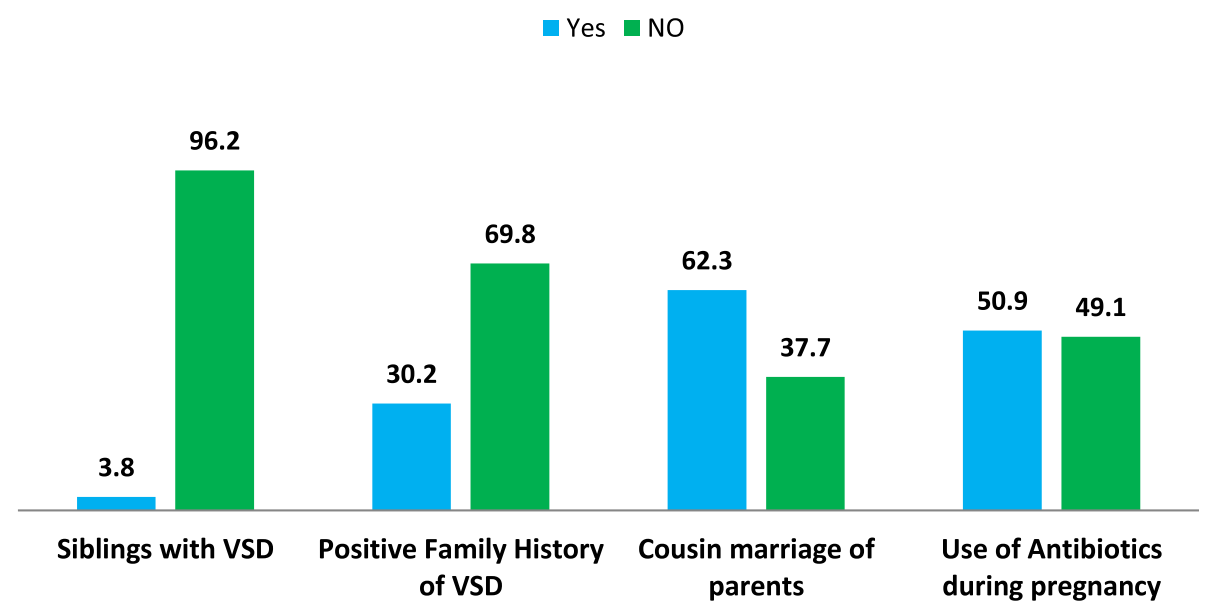

Fig. 3 Risk factors of VSD

\section{Conclusion}

The present work investigated the pattern of different parameters in Pakistani children with isolated VSDs. We observed that all attested parameters were altered in VSD patients. To the best of our knowledge, the present study is the first to report data on these parameters and risk factors associated with VSDs in Pakistani population. The current results emphasize the need of further investigation of these parameters in larger cohorts in the future. This data may have implication on the characterization and diagnosis of VSDs as well as on the assessment of related various factors. Parameters mentioned previously are not the risk factors for the congenital heart disease like VSDs, rather these parameters are deviated from normal range in individuals suffering from the developmental anomalies of the heart.

\section{Abbreviations}

VSDs: Ventricular septal defects; CHDs: Congenital heart defects; PDA: Patent ductus arteriosus; PT: Prothrombin time; APTT: Activated partial thromboplastin time; WBCs: White blood cells; RBCs: Red blood cell count; $\mathrm{Hb}$ : Hemoglobin level; BUN: Blood urea nitrogen; LFTs: Liver function tests; SGPT: Serum glutamic pyruvic transaminase; SGOT: Serum glutamic oxaloacetic transaminase; ALP: Alkaline phosphatase

\section{Acknowledgements}

We would like to acknowledge medical institutes for providing blood samples and other related data.

\section{Authors' contributions}

SS, AT, MJ, and FE performed the experiments, analyzed the results, and wrote the manuscript. SUS, AK, and SNH designed the study and assisted in sample collection; SS helped in performing experiments and assisted in statistical analysis and manuscript writing. NAS and SH designed and supervised the study, reviewed the paper, and provided technical support. All authors read and approved the final manuscript.

\section{Funding}

Not applicable
Availability of data and materials

The datasets for this manuscript are not publicly available because it is a part of the PhD research work of Miss Sumbal Sarwar. Requests to access the datasets should be directed to Sumbal Sarwar, email sumbal.sarwar@ymail. com.

\section{Ethics approval and consent to participate}

All participants are less than 15 years of age. A written informed consent was obtained from the parents of the pediatric patient. The study protocol was approved by the Ethical Committee, School of Biological Sciences, University of the Punjab. Reference number is not available.

\section{Consent for publication}

There is no conflict of interests regarding the publication of this article.

\section{Competing interests}

There are no competing interests.

\section{Author details}

'Department of Microbiology and Molecular Genetics, University of the Punjab, Lahore 54590, Pakistan. ${ }^{2}$ Ittefaq Hospital Trust, Lahore, Pakistan.

${ }^{3}$ Children Hospital Lahore, Lahore, Pakistan.

Received: 16 April 2020 Accepted: 1 July 2020

Published online: 08 September 2020

\section{References}

1. Wang J, Mao J-H, Ding K-K, Xu W-J, Liu X-Y, Qiu X-B et al (2015) A novel NKX2.6 mutation associated with congenital ventricular septal defect. Pediatr Cardiol. 36(3):646-656

2. Penny DJ, Vick GW III (2011) Ventricular septal defect. The Lancet. 377(9771): 1103-1112

3. Shafer K, Brickner ME. Ventricular Septal Defect. Essential echocardiography: a companion to Braunwald's heart disease: Elsevier; 2018. p. 435-9. e1.

4. Rothstein P (2017) laizzo PA. Percutaneous atrial and ventricular septal defect closure device, Google Patents

5. Frank L (2018) Ventricular Septal Defect. Visual guide to neonatal cardiology. 145

6. Bellmann K, Perrot A, Rickert-Sperling S. Human genetics of ventricular septal defect. Congenital heart diseases: the broken heart: Springer; 2016. p. 307-328.

7. Sathasivam K (2017) Uneasy neighbors: India, Pakistan and US foreign policy: Routledge 
8. Umair M, Ahmad F, Ullah A (2018) Whole exome sequencing as a diagnostic tool for genetic disorders in Pakistan. Pakistan Journal of Medical Research. 57(2):90-91

9. Aslamkhan M (2015) Clinical genetics and genetic counselling in Pakistan. Journal of Genes and Cells. 1(2):31

10. Bhardwaj R, Rai SK, Yadav AK, Lakhotia S, Agrawal D, Kumar A, et al. Epidemiology of congenital heart disease in India. Congenital heart disease. 2015;10(5):437-446

11. Martin GR, Perry LW, Ferencz C (1989) Increased prevalence of ventricular septal defect: epidemic or improved diagnosis. Pediatrics. 83(2):200-203

12. Meberg A, Otterstad J, Frøland G, Søarland S, Nitter-Hauge S (1994) Increasing incidence of ventricular septal defects caused by improved detection rate. Acta Paediatrica. 83(6):653-657

13. Hassan I, Haleem AA, Bhutta ZA (1997) Profile and risk factors for congenital heart disease. JPMA. 47(2):78-80

14. Aman W, Sherin A, Hafizullah M (2011) Frequency of congenital heart diseases in patients under the age of twelve years at Lady Reading Hospital Peshawar. JPMI. 20(1):64-69

15. Burki MK, Babar GS (2001) Prevalence and pattern of congenital heart disease in Hazara. JAMC. 13(4):16-18

16. Sadiq M, Roshan B, Khan A, Latif F, Bashir I, Sheikh S (2002) Pattern of pediatric heart diseases in Pakistan. JCPSP 12(3):149-153

17. Pate $\mathrm{N}$, Jawed $\mathrm{S}$, Nigar $\mathrm{N}$, Junaid F, Wadood AA, Abdullah F (2016) Frequency and pattern of congenital heart defects in a tertiary care cardiac hospital of Karachi. PJMS. 32(1):79-84

18. Shafi T, Khan M, Atiq M (2003) Congenital heart disease and associated malformations in children with cleft lip and palate in Pakistan. Br J Plast Surg. 56(2):106-109

19. Soranzo N, Spector TD, Mangino M, Kühnel B, Rendon A, Teumer A et al (2009) A genome-wide meta-analysis identifies 22 loci associated with eight hematological parameters in the HaemGen consortium. Nat Genet. 41(11):1182

20. Robles BN, Macri R, Xiong M, Jafri S, Vitale A, Beata V, et al. Prevalence of anemia in preschool aged children living in dominica. Am Acad Pediatrics; 2018.

21. Valiathan $R$, Ashman M, Asthana D (2016) Effects of ageing on the immune system: infants to elderly. Scand J Immunol. 83(4):255-266

22. Yip C, Linden MD, Attard C, Monagle P, Ignjatovic V (2015) Platelets from children are hyper-responsive to activation by thrombin receptor activator peptide and adenosine diphosphate compared to platelets from adults. $\mathrm{Br} \mathrm{J}$ Haematol. 168(4):526-532

23. Oladunjoye OO, Sleeper LA, Nair AG, Trenor III CC, VanderPluym C, Kheir JN, et al. Partial thromboplastin time is more predictive of bleeding than antiXa levels in heparinized pediatric patients after cardiac surgery. The Journal of thoracic and cardiovascular surgery. 2018;156(1):332-40. e1.

24. Ali NMA, Gameel FEMH, Elsayid M, Babker AMAAA (2016) Alterations in DDimer, Prothrombin time and activated partial thromboplastin time as thrombogenesis activity markers in patients with acute myocardial infarction. Open Journal of Blood Diseases. 6(01):1

25. Jujo K, Minami Y, Haruki S, Matsue Y, Shimazaki K, Kadowaki H et al (2017) Persistent high blood urea nitrogen level is associated with increased risk of cardiovascular events in patients with acute heart failure. ESC heart failure. 4(4):545-553

26. Brisco MA, Zile MR, Ter Maaten JM, Hanberg JS, Wilson FP, Parikh C et al (2016) The risk of death associated with proteinuria in heart failure is restricted to patients with an elevated blood urea nitrogen to creatinine ratio. Int J Cardiol. 215:521-526

27. Farquhar WB, Edwards DG, Jurkovitz CT, Weintraub WS (2015) Dietary sodium and health: more than just blood pressure. J Am Coll Cardiol. 65(10):1042-1050

28. Chen Q, Zhang Y, Ding D, Li D, Yang Y, Li Q et al (2018) Associations between serum calcium, phosphorus and mortality among patients with coronary heart disease. Eur J Nutr. 57(7):2457-2467

29. Ford RM, Book W, Spivey JR (2015) Liver disease related to the heart. Transplant Rev. 29(1):33-37

30. Hanada S, Kudo T, Kanzaki T, Sakata K, Iwakiri H (2017) Association between liver function and peak oxygen uptake in heart failure patients: a retrospective observational study. Progress in Rehabilitation Medicine. 2: 20170014

31. Yamazoe M, Mizuno A, Nishi Y, Niwa K, Isobe M (2016) Serum alkaline phosphatase as a predictor of worsening renal function in patients with acute decompensated heart failure. J Cardiol. 67(5):412-417
32. Biegus J, Hillege HL, Postmus D, Valente MA, Bloomfield DM, Cleland JG et al (2016) Abnormal liver function tests in acute heart failure: relationship with clinical characteristics and outcome in the PROTECT study. European journal of heart failure. 18(7):830-839

33. Butt SJ, Malik S, Malik H, Butt AJ (2018) ABO and Rhesus blood grouping in voluntary blood donors and its gender association. Pak J Med Health Sci. 12(1):268-271

34. Butt DS, Malik S, Khalid MZ, Aziz M, Humayun A. Gender distribution of ABO and Rhesus blood groups among medical students of a public medical school in Lahore, Pakistan. Proceeding Shaikh Zayed Postgrad Med Comp. 2016;30(2):77â.

35. Asif M, Manzoor SM, Ahmad M, Younis MZ (2018) Frequency of $A B O$ and $\mathrm{RH}$ (D) blood groups among recruits; resident of surrounding areas of Dera Ismail Khan. Pakistan Journal of Pathology. 29(4):69-71

36. Majeed-Saidan MA, Atiyah M, Ammari AN, AlHashem AM, Rakaf MS, Shoukri MM et al (2019) Patterns, prevalence, risk factors, and survival of newborns with congenital heart defects in a Saudi population: a three-year, cohort case-control study. Journal of Congenital Cardiology. 3(1):2

37. Eichler A, Köhler-Jonas N, Stonawski V, Purbojo A, Moll GH, Heinrich H et al (2019) Child neurodevelopment and mental health after surgical ventricular septal defect repair: risk and protective factors. Dev Med Child Neurol. 61(2): $152-160$

\section{Publisher's Note}

Springer Nature remains neutral with regard to jurisdictional claims in published maps and institutional affiliations.

\section{Submit your manuscript to a SpringerOpen ${ }^{\circ}$ journal and benefit from:}

- Convenient online submission

- Rigorous peer review

- Open access: articles freely available online

- High visibility within the field

- Retaining the copyright to your article

Submit your next manuscript at $>$ springeropen.com 